\title{
PERLINDUNGAN HAK ANAK DALAM PEMERIKSAAN PERKARA PERMOHONAN DISPENSASI KA WIN
}

\author{
Mudawamah \\ Pengadilan Agama Badung, Bali \\ Email : mudae60@gmail.com
}

\begin{abstract}
Abstrak
Jurnal dengan judul "Perlindungan Hak Anak Dalam Pemeriksaan Perkara Permohonan Dispensasi Kawin" ini berangkat dari permasalahan bagaimana bentuk perlindungan hak anak dalam pemeriksaan perkara permohonan dispensasi kawin dan bagaimanana implikasi hukum dispensasi kawin dalam rangka perlindungan hak anak. Penelitian ini bertujuan untuk menganalisis dan menjelaskan perlindungan hak anak dalam pemeriksaan perkara permohonan Dispensasi Kawin dan juga implikasi hukum Dispensasi Kawin dalam rangka perlindungan hak anak. Penelitian ini termasuk penelitian yuridis normatif. Penelitian ini menggunakan pendekatan perundang-undangan dan pendekatan konseptual. Sumber bahan hukum dalam penelitian ini terdiri dari bahan hukum primer, bahan hukum sekunder dan bahan hukum tersier. Analisis penelitian ini dilakukan dengan analisis deskripstif kualitatif. Berdasarkan hasil penelitian, dapat disimpulkan bahwa perlindungan hak anak selama proses pemeriksaan perkara permohonan Dispensasi Kawin mengacu pada UU Perkawinan dan juga Perma Nomor 5 Tahun 2019 tentang Pedoman Mengadili Permohonan Dispensasi Kawin. Adapun bentuk perlindungan hak anak dalam pemeriksaan perkara permohonan Dispensasi Kawin meliputi: 1) Diperiksa oleh Hakim Tunggal yang kompeten, 2) Memberikan rasa nyaman di persidangan, 3) Menghadirkan anak dalam proses pemeriksaan, 4) Hakim menghadirkan dan memberi nasihat kepada Orang Tua, Anak, Calon Suami/Isteri dan Orang Tua/Wali Calon Suami/Isteri, 5) Mengutamakan kepentingan terbaik untuk anak, dan 6) Pertimbangan hukum oleh hakim yang mewujudkan kepastian, kemanfaatan dan keadilan bagi anak. Permohonan Dispensasi Kawin menimbulkan implikasi hukum baik permohonan tersebut dikabulkan ataupun ditolak. Dalam memberikan pertimbangan hukum atas permohonan Dispensasi Kawin tersebut, hakim harus mengutamakan kepentingan terbaik bagi anak dengan mempertimbangkan moral, agama, adat dan budaya, aspek psikologis, aspek kesehatan, dan dampak yang ditimbulkan untuk mewujudkan kepastian, kemanfaatan dan keadilan bagi anak.
\end{abstract}

Kata kunci: Perlindungan Hak Anak, Dispensasi Kawin

\begin{abstract}
The journal related to "The Protection of the Rights of the Child in Examination of Cases of Application for Marriage Dispensation" departs from the problem of how to protect children's rights in examining cases of applications for marriage dispensation and how are the legal implications of marriage dispensation in the context of protecting children's rights. This study aims to analyze and explain the
\end{abstract}




\section{Jurnal Negara dan $\mathcal{X}$ eadilan \\ p-ISSN 2302-7010 e-ISSN 2721-9801}

protection of children's rights in examining cases of applications for marriage dispensation and also the legal implications of marriage dispensation in the context of protecting children's rights. This research is a normative juridical research. This study uses a statutory approach and a conceptual approach. The sources of legal materials in this study consist of primary legal materials, secondary legal materials and tertiary legal materials. The analysis of this research was carried out by means of a qualitative descriptive analysis. Based on the results of the research, it can be concluded that the protection of children's rights during the process of examining cases of marriage dispensation applications refers to the Marriage Law and also Supreme Court regulations Number 5 of 2019 concerning Guidelines for Adjudicating Applications for Marriage Dispensation. The forms of protection of children's rights in the examination of cases of application for Marriage Dispensation include: 1) The examination by a competent single judge, 2) Providing a sense of comfort at court, 3) Presenting children in the examination process, 4) The Judge presents and advises parents, children, candidate for husband / wife and parents / guardian of candidate husband / wife, 5) Prioritizing the best interests of the child, and 6) Legal considerations by the judge that realize certainty, benefit and justice for the children. An application for marriage dispensation has legal implications whether the application is granted or rejected. In providing legal considerations for the request for the marriage dispensation, the judge must prioritize the best interests of the child by considering the moral, religious, customary and cultural aspects, psychological aspects, health aspects, and the impact that is created to create certainty, benefit and justice for the child.

Keywords: Protection of Children's Rights, Marriage Dispensation

\section{PENDAHULUAN}

Indonesia merupakan negara hukum yang menjamin hak-hak setiap warga negaranya, termasuk hak untuk membentuk keluarga dan melanjutkan keturunan melalui perkawinan yang sah. Hukum positif di Indonesia mengatur batas usia diperbolehkan untuk melangsungkan perkawinan diatur dalam Pasal 7 ayat (1) Undang-Undang Nomor 16 Tahun 2019 tentang Perubahan atas Undang-Undang Nomor 1 Tahun 1974 tentang Perkawinan bahwa Perkawinan hanya diizinkan apabila pria dan wanita sudah mencapai umur 19 (sembilan belas) tahun. Ketentuan tersebut secara eksplisit menjelaskan bahwa setiap perkawinan yang dilakukan oleh pria dan wanita yang belum mencapai umur 19 (sembilan belas) tahun disebut sebagai "perkawinan di bawah umur". Bagi pria dan wanita yang berusia di bawah ketentuan tersebut, pada hakikatnya disebut sebagai anak karena belum dewasa untuk melangsungkan perkawinan sebagaimana yang telah ditentukan tersebut.

Anak sebagai generasi muda yang akan menjadi penerus cita-cita perjuangan bangsa memang harus mendapatkan perlindungan dengan menjamin pertumbuhan dan perkembangan fisik, mental dan sosial secara utuh, serasi dan seimbang. Undang-Undang Nomor 16 Tahun 2019 tentang Perubahan atas Undang-Undang Nomor 1 Tahun 1974 tentang Perkawinan rupanya mencoba untuk memberikan salah satu solusi untuk menekan angka perkawinan di bawah umur, yaitu menambah batas minimum usia perkawinan untuk pria dan wanita 


\section{Hurnal Negara dan $\mathcal{X}$ eadilan \\ p-ISSN 2302-7010 e-ISSN 2721-9801}

menjadi berusia 19 tahun $^{1}$ yang sebelumnya untuk pria adalah 19 tahun dan untuk wanita adalah 16 tahun sebagaimana yang diatur dalam Undang-Undang Nomor 1 Tahun 1974. Adapun pertimbangan penambahan usia minimum perkawinan dalam Undang-Undang tersebut adalah bahwa perkawinan pada usia anak menimbulkan dampak negatif bagi tumbuh kembang anak dan akan menyebabkan tidak terpenuhinya hak dasar anak seperti hak atas perlindungan dari kekerasan dan diskriminasi, hak sipil anak, hak kesehatan, hak pendidikan, dan hak sosial anak.

Untuk menjamin kepastian hukum dalam hal terjadi perkawinan oleh pria dan wanita yang belum berumur 19 tahun, maka sebagaimana Pasal 7 ayat (2) Undang-Undang Perkawinan mengatur langkah hukum yang dapat dilakukan bagi mereka yang tidak memenuhi syarat batas minimal usia perkawinan. Dalam ketentuan pasal tersebut menyebutkan bahwa "Dalam hal terjadi penyimpangan terhadap ketentuan umur tersebut, maka orang tua pihak pria dan/atau orang tua pihak wanita dapat meminta dispensasi kepada Pengadilan dengan alasan sangat mendesak disertai bukti-bukti pendukung yang cukup". ${ }^{2}$

Dispensasi Kawin tersebut memang diajukan kepada pengadilan oleh orang tua calon mempelai karena calon mempelai pria atau wanita yang belum cukup umur untuk melangsungkan perkawinan tersebut dianggap belum cakap hukum. Pasal 330 KUH Perdata menentukan bahwa yang dimaksud belum dewasa adalah anak yang belum genap berusia 21 tahun atau belum menikah. Anak-anak yang masuk kategori tersebut belum memiliki legal standing untuk mengajukan suatu permohonan di pengadilan. Akan tetapi, dalam proses pemeriksaan perkara dispensasi kawin oleh Pengadilan sebagaimana dalam ketentuan Peraturan Mahkamah Agung Nomor 5 Tahun 2019 tentang Pedoman Mengadili Permohonan Dispensasi Kawin, hakim wajib mendengarkan pendapat kedua belah calon mempelai yang akan melangsungkan perkawinan, sehingga dalam hal ini anak dilibatkan dalam proses pemeriksaan dispensasi kawin. Oleh karena itu perlu ada perlindungan khusus untuk melindungi hak-hak anak yang terlibat dalam proses pemeriksaan perkara Dispensasi Kawin.

Berangkat dari latar belakang masalah di atas, maka dapat dirumuskan masalah sebagai berikut:

1. Bagaimana bentuk perlindungan hak anak dalam pemeriksaan perkara permohonan dispensasi kawin?

2. Bagaimana implikasi hukum dispensasi kawin dalam rangka perlindungan hak anak?

\section{METODE PENELITIAN}

Penelitian ini termasuk penelitian yuridis normatif. Penelitian ini menggunakan pendekatan perundang-undangan dan pendekatan konseptual. Sumber bahan hukum dalam penelitian ini terdiri dari sumber bahan hukum primer, sekunder dan tersier. Analisis penelitian ini dilakukan dengan analisis deskripstif kualitatif.

\footnotetext{
${ }^{1}$ Pasal 7 ayat (1) UU Nomor 16 Tahun 2019

${ }^{2}$ Pasal 7 ayat (2) UU Nomor 16 Tahun 2019
} 


\section{Hurnal Negara dan $\mathcal{X}$ eadilan \\ p-ISSN 2302-7010 e-ISSN 2721-9801}

\section{PEMBAHASAN}

\section{Bentuk Perlindungan Hak Anak dalam Pemeriksaan Perkara Permohonan Dispensasi Kawin}

Pemerintah memberikan perlindungan hukum bagi anak yang belum memenuhi syarat usia untuk melangsungkan perkawinan dengan melalui permohonan dispensasi kawin sebagaimana ketentuan Pasal 7 ayat (2) UU Nomor 16 Tahun 2019. Tentunya hal tersebut alasan sangat mendesak yaitu keadaan di mana tidak ada pilihan lain dan sangat terpaksa harus dilangsungkan perkawinan atau dalam arti lain apabila tidak diberikan dispensasi kawin akan menimbulkan bahaya. Permohonan dispensasi kawin tersebut diajukan oleh orang tua calon mempelai kepada pengadilan karena calon mempelai yang akan melangsungkan perkawinan belum cakap hukum sebagaimana Pasal 330 BW menentukan bahwa belum dewasa adalah anak yang belum genap berusia 21 tahun atau belum menikah, sehingga calon mempelai tersebut belum memiliki legal standing untuk mengajukan permohonan dispensasi kawin di pengadilan. Namun demikian, dalam proses pemeriksaan perkara permohonan dispensasi kawin, pengadilan wajib mendengarkan pendapat kedua belah calon mempelai yang akan melangsungkan perkawinan. Oleh karena itu, dalam pemeriksaan perkara permohonan dispensasi kawin, pengadilan dalam hal ini Hakim yang memeriksa perkara tersebut harus tetap memberikan perlindungan terhadap hak-hak anak untuk memastikan bahwa tidak ada pelanggaran terhadap hak anak karena pengadilan sebagai salah satu unsur yang wajib menyelenggarakan perlindungan anak.

Mahkamah Agung mengeluarkan petunjuk teknis penanganan perkara dispensasi kawin berupa Peraturan Mahkamah Agung (PERMA) Nomor 5 Tahun 2019 tentang Pedoman Mengadili Permohonan Dispensasi Kawin yang diberlakukan sejak tanggal 21 November 2019. Salah satu tujuan dibuatnya pedoman tersebut adalah untuk menjamin standarisasi proses mengadili dispensasi kawin di Pengadilan demi melindungi hak-hak anak.

Adapun bentuk perlindungan kepada hak anak dalam proses pemeriksaan perkara Dispensasi Kawin saat persidangan di pengadilan sebagaimana telah diatur dalam ketentuan Peraturan Mahkamah Agung Nomor 5 Tahun 2019 tentang Pedoman Mengadili Permohonan Dispensasi Kawin, yaitu antara lain sebagai berikut:

a.Diperiksa oleh Hakim Tunggal yang kompeten.

Selama proses pemeriksaan di pengadilan, anak diperlakukan sesuai dengan usianya yang masih dalam kategori anak. Pemeriksaannya dibedakan dengan pemeriksaan orang dewasa, hal tersebut bukanlah sebuah diskriminasi, akan tetapi sebagai bentuk perlindungan hak anak agar anak merasa tenang dan tidak merasa takut saat dimintai keterangan oleh hakim. Selain itu, pemeriksaan juga dilakukan oleh hakim tunggal yang memiliki kompetensi mengadili anak, sehingga dalam mengadili permohonan Dispensasi Kawin benar-benar dilakukan oleh hakim yang mumpuni dalam bidangnya. Hal tersebut sebagaimana ketentuan Pasal 11 Perma Nomor 5 Tahun 2019, bahwa dalam pemeriksaan dispensasi kawin diperiksa oleh hakim tunggal yang memiliki kemampuan mengadili anak. Hakim tersebut sudah memiliki surat keputusan Ketua Mahkamah Agung sebagai 


\section{Zurnal Negara dan $\mathcal{X}$ eadilan \\ p-ISSN 2302-7010 e-ISSN 2721-9801}

Hakim Anak, mengikuti pelatihan dan/atau bimbingan teknis tentang perempuan berhadapan dengan hukum atau hakim tersebut telah bersertifikat sistem peradilan pidana anak atau sudah berpengalaman mengadili permohonan dispensasi kawin.

b.Memberikan rasa nyaman di persidangan.

Pemeriksaan permohonan Dispensasi Kawin dilakukan berbeda dengan pemeriksaan perkara orang dewasa. Selama proses pemeriksaan permohonan dispensasi kawin, sebagaimana ketentuan Pasal 11 ayat (2) Perma Nomor 5 Tahun 2019, bahwa Hakim dan Panitera Pengganti tidak menggunakan atribut persidangan seperti toga dan dasi untuk hakim dan jas untuk Panitera Pengganti. Hakim dan Panitera Pengganti menggunakan pakaian formal tanpa atribut persidangan. Atribut persidangan tersebut akan membawa image "menakutkan", sehingga mempengaruhi mental anak dalam menyampaikan keterangannya.

Selain itu, hakim harus menggunakan bahasa dan metode yang mudah dipahami dan dimengerti anak (Pasal 11 ayat (1) Perma Nomor 5 Tahun 2019). Ketentuan ini bertujuan agar anak tidak merasa tertekan dan terbebani sehingga anak dapat menyampaikan informasi dengan tenang, baik dan benar.

Dalam Perma Nomor 5 Tahun 2019 belum mengatur bahwa sidang pemeriksaan perkara permohonan Dispensasi Kawin dilakukan dalam sidang tertutup untuk umum. Seharusnya sidang dilakukan tertutup untuk umum karena untuk melindungi privasi anak. Apabila sidang dilakukan terbuka untuk umum, maka bisa jadi akan memberikan pandangan negative orang lain terhadap anak tersebut karena akan melakukan perkawinan di bawah umur.

c.Menghadirkan anak dalam proses pemeriksaan.

Dalam pemeriksaan permohonan Dispensasi Kawin, hakim wajib menghadirkan anak. Sebagaimana ketentuan dalam Pasal 7 ayat (3) UU Nomor 16 Tahun 2019 bahwa pemberian dispensasi oleh Pengadilan wajib mendengarkan pendapat kedua belah calon mempelai yang akan melangsungkan perkawinan. Begitu pula diatur dalam Pasal 10 Perma Nomor 5 tahun 2019 mengatur bahwa pada saat sidang pertama, Pemohon wajib menghadirkan sejumlah pihak untuk dimintai keterangan yaitu (1) anak yang dimintakan permohonan Dispensasi Kawin, (2) calon suami/isteri, dan (3) Orang Tua/Wali calon suami/isteri. Kesempatan menghadirkan pihak-pihak tersebut sampai tundaan sidang yang ketiga, sehingga perintah menghadirkan pihak anak sangat urgen, bahkan apabila tidak dihadirkan, maka permohonan Dispensasi Kawin tidak dapat diterima.

Menghadirkan anak dalam persidangan bertujuan untuk dimintai keterangannya. Dengan memastikan memang perkawinan di bawah umur tersebut dilakukan tanpa adanya unsur paksaan dan kesiapannya saat sudah menikah nanti. Anak merasa tidak dipaksaan oleh orang tua dan benar-benar sudah mengetahui dampak yang akan timbul jika melakukan perkawinan di bawah umur. Sebagaimana ketentuan dalam Pasal 6 UU Perkawinan bahwa salah satu syarat perkawinan adalah perkawinan harus didasarkan atas persetujuan kedua calon mempelai.

Pada saat menggali keterangan anak, hakim mendengar keterangan anak secara terpisah dengan orang tua. Pemeriksaan juga dapat dilakukan secara virtual apabila terdapat kendala jarak dengan mendengar keterangan anak melalui pemeriksaan komunikasi audio visual jarak jauh di pengadilan setempat atau di tempat lain. Apabila dibutuhkan, Hakim dapat menyarankan agar anak didampingi Pendamping dan dapat meminta rekomendasi dari Psikolog atau Dokter/Bidan, 


\section{$\mathcal{H}$ urnal Negara dan Keadilan \\ p-ISSN 2302-7010 e-ISSN 2721-9801}

Pekerja Sosial Profesional, Tenaga Kesejahteraan Sosial, Pusat Pelayanan Terpadu Perlindungan Perempuan dan Anak (P2TP2A), Komisi Perlindungan Anak Indonesia/Daerah (KPAI/KPAD) dan menghadirkan penerjemah/orang yang biasa berkomunikasi dengan Anak (Pasal 15 Perma 5/2019).

Dalam memeriksa dan menggali keterangan anak, hakim mengidentifikasi hal-hal sebagai berikut:

a. Anak yang diajukan dalam permohonan mengetahui dan menyetujui rencana perkawinan;

b. kondisi psikologis, kesehatan dan kesiapan Anak untuk melangsungkan perkawinan dan membangun kehidupan rumahtangga; dan

c. paksaan psikis, fisik, seksual atau ekonomi terhadap anak dan/ atau keluarga untuk kawin atau mengawinkan Anak. (Pasal 14 Perma 5/2019).

Meminta keterangan anak dalam persidangan ini sebagai bentuk perlindungan hak anak dalam hal penghargaan terhadap pendapat anak. Sebagaimana ketentuan dalam Pasal 10 UU Nomor 23 Tahun 2002 tentang Perlindungan Anak sebagaimana telah diubah dengan UU Nomor 35 Tahun 2014 bahwa setiap anak berhak menyatakan dan didengar pendapatnya, menerima, mencari, dan memberikan informasi sesuai dengan tingkat kecerdasan dan usianya demi pengembangan dirinya sesuai dengan nilai-nilai kesusilaan dan kepatutan. Selain itu juga, sebagaimana Pasal 24 UU Perlindungan Anak bahwa Negara, Pemerintah, dan Pemerintah Daerah menjamin Anak untuk mempergunakan haknya dalam menyampaikan pendapat sesuai dengan usia dan tingkat kecerdasan Anak. Hal tersebut juga selaras dengan maksud dari ketentuan Pasal 12 Konvensi Hak Anak yang menyatakan bahwa negara-negara peserta juga harus menjamin hak anak untuk menyatakan pandangannya secara bebas terkait semua hal yang menyangkut anak yang dinilai sesuai dengan usia dan kematangan anak yang bersangkutan. Anak juga akan diberikan kesempatan yang sama untuk didengar pendapatnya dalam proses peradilan dan segala urusan administrasi yang menyangkut anak baik langsung ataupun diwakili.

Dengan didengarkannya keterangan anak, Hakim dapat mengetahui kondisi anak serta kebutuhan apa saja yang dapat dipenuhi untuk anak serta permasalahan-permasalahan yang dihadapi oleh anak, karena terkadang hal tersebut tidak didapat hanya dari keterangan pihak orang tua dari anak saja. Keterangan anak tersebut dapat diperkuat dengan bukti-bukti lain, misalnya dengan hasil visum, hasil asesmen lembaga perlindungan anak, dan bahkan juga dapat menghadirkan ahli di persidangan. Dengan demikian, Hakim dapat memberikan putusan yang adil dengan mencantumkan perspektif anak di dalamnya.

d.Hakim menghadirkan dan memberi nasihat kepada Orang Tua, Anak, Calon Suami/Isteri dan Orang Tua/Wali Calon Suami/Isteri.

Pemeriksaan perkara dispensasi kawin dilakukan dengan memberikan nasihat kepada para pihak yang dihadirkan dalam persidangan yaitu Orang Tua, Anak, Calon Suami/Isteri dan Orang Tua/Wali Calon Suami/Isteri agar memahami risiko perkawinan, terkait dengan:

1) kemungkinan berhentinya pendidikan bagi anak;

2) keberlanjutan anak dalam menempuh wajib belajar 12 tahun;

3) belum siapnya organ reproduksi anak;

4) dampak ekonomi, sosial dan psikologis bagi anak; dan 


\section{Hurnal Negara dan $\mathcal{X}$ eadilan \\ p-ISSN 2302-7010 e-ISSN 2721-9801}

5) potensi perselisihan dan kekerasan dalam rumah tangga.

Pemohon harus menghadirkan pihak-pihak tersebut di persidangan dengan memberi kesempatan sampai tundaan sidang yang ketiga. Jika pada hari sidang ketiga Pemohon juga tidak dapat menghadirkan pihak-pihak tersebut, maka permohonan Dispensasi Kawin tidak dapat diterima. Ketentuan tersebut memperhatikan betapa pentingnya keterlibatan pihak-pihak tersebut dalam pemeriksaan dispensasi kawin untuk dimintai keterangannya. Keterlibatan pihak selain anak, yaitu orang tua anak dan orang tua calon suami/istri dalam pemeriksaan perkara dispensasi kawin untuk memberikan pemahaman kepada pihak tersebut dampak perkawinan di bawah umur karena keluarga adalah pihak terdekat anak yang sangat berpengaruh pada anak. Selain itu juga memastikan bahwa permohonan dispensasi kawin tersebut tidak merampas hak-hak anak yang dilakukan oleh pihak-pihak tersebut. Pihak terkait harus turut andil untuk mencegah perkawinan di bawah umur. Jika perkawinan di bawah umur tetap dilaksanakan, maka akan memberikan berbagai dampak terhadap anak. Anak yang seharusnya masih memiliki masa depan untuk mencapai cita-citanya, akan tetapi harus berhenti karena harus mengurus rumah tangga. Pendidikan pun akan berhenti sehingga tidak bisa mengembangkan potensinya. Anak tidak lagi bisa mengekspresi diri dan berpikir sesuai dengan usianya karena dituntut melaksanakan kewajiban sebagai suami atau isteri. Hal tersebut telah membatasi hak yang dimiliki anak karena tidak dapat menyelesaikan pendidikan dasarnya dan kehilangan kemerdekaannya untuk berkembang sebagai anak karena telah menikah di usia anak.

Dengan memberikan nasihat mengenai kelima hal tersebut, maka Hakim dalam pemeriksaan perkara permohonan Dispensasi Kawin telah berusaha melindungi hak anak terkait hak atas pendidikan, hak atas kesehatan, serta hak untuk tumbuh dan berkembang yang telah dijamin pemenuhan dan perlindungannya oleh UUD 1945. Selain itu juga, orang tua sebagai salah satu pihak yang berperan dalam penyelenggaraan perlindungan anak, sehingga sangat dibutuhkan keterangannya dalam pemeriksaan dispensasi kawin, sebagaimana ketentuaan Pasal 20 UU Nomor 35 Tahun 2014 yang manyatakan bahwa Negara, Pemerintah, Pemerintah Daerah, Masyarakat, Keluarga, dan Orang Tua atau Wali berkewajiban dan bertanggung jawab terhadap penyelenggaraan Perlindungan Anak.

e.Mengutamakan kepentingan terbaik untuk anak.

Salah satu prinsip perlindungan anak adalah dengan mengedepankan kepentingan terbaik bagi anak. Dalam memeriksa permohonan Dispensasi Kawin, Hakim mengutamakan kepentingan terbaik bagi anak sebagai bentuk perlindungan terhadap anak dengan:

1) mempelajari secara teliti dan cermat permohonan pemohon;

2) memeriksa kedudukan hukum pemohon;

3) menggali latar belakang dan alasan perkawinan Anak;

4) menggali informasi terkait ada tidaknya halangan perkawinan;

5) menggali informasi terkait dengan pemahaman dan persetujuan Anak untuk dikawinkan;

6) memperhatikan perbedaan usia antara anak dan calon suami/ isteri;

7) mendengar keterangan pemohon, anak, calon suami/isteri, dan orang tua/wali calon suami/isteri; 


\section{$\mathcal{H}$ urnal Negara dan Keadilan \\ p-ISSN 2302-7010 e-ISSN 2721-9801}

8) mempertimbangkan kondisi psikologis, sosiologis, budaya, pendidikan, kesehatan, ekonomi anak dan orang tua, berdasarkan rekomendasi dari Psikolog, Dokter/Bidan, Pekerja Sosial Profesional, Tenaga Kesejahteraan Sosial, Pusat Pelayanan Terpadu Perlindungan Perempuan dan Anak (P2TP2A) atau Komisi Perlindungan Anak Indonesia/Daerah (KPAI/KPAD);

9) mempertimbangkan ada atau tidaknya unsur paksaan psikis, fisik, seksual dan/ atau ekonomi; dan

10) memastikan komitmen Orang Tua untuk ikut bertanggungjawab terkait masalah ekonomi, sosial, kesehatan, dan pendidikan Anak. (Pasal 16 perma 5/2019).

Pertimbangan hukum oleh hakim yang mewujudkan kepastian, kemanfaatan dan keadilan bagi anak. Dalam memberikan pertimbangan hukum, Hakim harus mempertimbangkan hal-hal sebagai berikut agar mewujudkan tujuan hukum yang meliputi kepastian, kemanfaatan dan keadilan bagi anak, sehingga terwujudlah perlindungan hak anak: ${ }^{3}$

1) Pertimbangan tentang penasehatan hakim kepada Pemohon, Anak, Calon Suami/Isteri dan Orang Tua/Wali Calon Suami/Isteri agar memahami risiko perkawinan, terkait dengan: kemungkinan berhentinya pendidikan bagi anak, keberlanjutan anak dalam menempuh wajib belajar 12 tahun, belum siapnya organ reproduksi anak; dampak ekonomi, sosial dan psikologis bagi anak; dan potensi perselisihan dan kekerasan dalam rumah tangga. (Pasal 12 perma 5/2019).

2) Pertimbangan tentang bahwa hakim sudah mendengar keterangan anak yang dimintakan Dispensasi Kawin; calon suami/isteri yang dimintakan Dispensasi Kawin; orang tua/wali anak yang dimohonkan Dispensasi Kawin; dan orang tua/wali calon suami/isteri. (Pasal 13 Perma 5/2019).

3) Pertimbangan tentang Anak yang diajukan dalam permohonan mengetahui dan menyetujui rencana perkawinan; pertimbangan tentang kondisi psikologis, kesehatan dan kesiapan Anak untuk melangsungkan perkawinan dan membangun kehidupan rumahtangga; dan pertimbangan tentang ada atau tidaknya paksaan psikis, fisik, seksual atau ekonomi terhadap anak dan/ atau keluarga untuk kawin atau mengawinkan Anak. (Pasal 14 Perma 5/2019).

4) Pertimbangan tentang perlindungan dan kepentingan terbaik bagi anak sebagaimana diatur dalam peraturan perundang-undangan dan hukum tidak tertulis dalam bentuk nilai-nilai hukum, kearifan lokal, dan rasa keadilan yang hidup dalam masyarakat; dan konvensi dan/atau perjanjian internasional terkait perlindungan anak. (pasal 17 perma 5/2019). Sebagaimana ketentuan Pasal 5 ayat (1) UU Nomor 48 Tahun 2009 tentang Kekuasaan Kehakiman bahwa Hakim dan hakim konstitusi wajib menggali, mengikuti, dan memahami nilai-nilai hukum dan rasa keadilan yang hidup dalam masyarakat. Adapun nilai-nilai yang hidup dalam masyarakat di Indonesia, misalnya kehormatan keluarga harus dijaga dan aib harus ditutupi, moralitas keluarga yang akan menjadi sorotan masyarakat, sehingga harus dijaga.

5) Pertimbangan tentang alasan sangat mendesak yaitu keadaan tidak ada pilihan lain dan sangat terpaksa harus dilangsungkan perkawinan dan pertimbangan

${ }^{3}$ Sugiri Permana dan Ahmad Zaenal Fanani, Dispensasi Kawin Dalam Hukum Keluarga di Indonesia, Kajian Atas Norma dan Praktek Hukum Acara Pasca Disahkannya UU No. 16 Tahun 2019 dan Perma Nomor 5 Tahun 2019, hlm. 35. 


\section{Hurnal Negara dan $\mathcal{X}$ eadilan \\ p-ISSN 2302-7010 e-ISSN 2721-9801}

tentang alasan tersebut disertai bukti yang cukup yaitu surat keterangan yang membuktikan bahwa usia mempelai masih di bawah ketentuan undangundang dan surat keterangan dari tenaga kesehatan yang mendukung pernyataan orang tua bahwa perkawinan tersebut sangat mendesak untuk dilaksanakan. (Pasal 7 ayat (2) UU Nomor 16 tahun 2019 dan penjelasannya).

6) Pertimbangan tentang perkawinan anak pemohon dengan calon suami/isteri tidak ada hubungan yang menghalangi untuk menikah baik hubungan darah maupun hubungan sepersusuan dan tidak sedang dalam pinangan orang lain serta tidak ada halangan lain baik yang terkait dengan syarat dan rukun pernikahan maupun syarat administratif kecuali hanya pihak calon mempelai belum mencapai umur 19 tahun. (Pasal 6, 7 dan 8 Undang-Undang Nomor 1 Tahun 1974 yang telah diubah dengan Undang-Undang Nomor 16 tahun 2019 tentang Perkawinan).

Implikasi Hukum Dispensasi Kawin dalam Rangka Perlindungan Hak Anak.

Pasca diundangkannya revisi UU Perkawinan yaitu UU Nomor 16 Tahun

2019 dengan mengubah Pasal 7 ayat (1) mengenai batasan minimal usia perkawinan bagi pria dan wanita menjadi masing-masing 19 tahun memberikan beberapa dampak di masyarakat, khususnya pada perkawinan di bawah umur. Sebagaimana pendapat Roscoe Pound dengan teorinya yaitu: "Law as a tool of social engineering" yaitu bahwa hukum adalah sebagai alat rekayasa sosial atau law as tool of development (hukum sebagai sarana pembangunan) sebagaimana dikemukakan oleh Mochtar Kusumaatmadja. ${ }^{4}$ Hukum sebagai alat rekayasa sosial diharapkan dapat terjadinya perubahan-perubahan yang mengarah pada kebaikan bagi masyarakat. Salah satu tujuan revisi batas usia untuk melangsungkan perakwinan tersebut adalah diharapkan dapat menekan angka perkawinan anak di bawah umur karena perkawinan pada usia anak menimbulkan dampak negatif bagi tumbuh kembang anak dan akan menyebabkan tidak terpenuhinya hak dasar anak seperti hak atas perlindungan dari kekerasan dan diskriminasi, hak sipil anak, hak kesehatan, hak pendidikan, dan hak sosial anak. ${ }^{5}$ Namun, UU Perkawinan juga memberikan peluang upaya hukum bagi mereka yang belum memenuhi syarat usia melangsungkan perkawinan atau penyimpangan terhadap batas usia perkawinan yang telah ditentukan, yaitu dengan mengajukan permohonan dispensasi kawin ke pengadilan. Hal tersebut sebagaimana yang diatur dalam Pasal 7 ayat (2) UU Perkawinan telah disebutkan bahwa dalam hal terjadi penyimpangan terhadap ketentuan umur sebagaimana dimaksud pada ayat (1), orang tua pihak pria dan/atau orang tua pihak wanita dapat meminta dispensasi kepada Pengadilan dengan alasan sangat mendesak disertai bukti-bukti pendukung yang cukup. Pengajuan permohonan dispensasi kawin tersebut harus atas dasar alasan yang sangat mendesak dan Pemohon harus dapat membuktikannya saat persidangan.

Dengan perubahan batas usia perkawinan tersebut, justru menyebabkan semakin banyaknya pengajuan permohonan dispensasi kawin di pengadilan, terutama di Pengadilan Agama karena sebagian besar masyarakat Indonesia beragama Islam. Adapun jumlah perkara dispensasi kawin yang masuk di seluruh

4 Mochtar Kusumaatmadja, Konsep-konsep Hukum dalam Pembangunan, (Bandung: Alumni, 2002), hlm. 88.

${ }^{5}$ Konsideran UU Nomor 16 Tahun 2019 


\section{$\mathcal{H}$ urnal Negara dan Keadilan \\ p-ISSN 2302-7010 e-ISSN 2721-9801}

Pengadilan Agama di Indonesia sebelum dan sesudah revisi UU Perkawinan sebagai berikut:

1.Sebelum perubahan UU Nomor 1 Tahun 1974, sejak bulan Januari sampai dengan bulan September 2019, jumlah perkara permohonan Dispensasi Kawin berjumlah 12.624 perkara atau rata-rata perkara setiap bulannya sekitar 1.403 perkara.

2.Pasca UU Nomor 1 Tahun 1974 diubah dengan UU Nomor 16 Tahun 2019, sejak bulan Januari sampai dengan bulan September 2020, jumlah perkara permohonan Dispensasi Kawin berjumlah 49.326 perkara atau dengan rata-rata per bulan sejumlah 5.480 perkara. ${ }^{6}$

Berdasarkan data di atas, dapat disimpulkan bahwa dengan bertambahnya batas usia perkawinan, semakin banyak masyarakat mengajukan permohonan Dispensasi Kawin. Fakta tersebut menunjukkan bahwa revisi Undang-Undang Perkawinan ternyata tidak sebanding dengan kesadaran hukum masyarakat.

Semakin tingginya tingkat perkara permohonan dispensasi kawin yang yang diajukan ke pengadilan, hakim pemeriksa perkara harus mempertimbangkan dengan baik dengan mempertimbangkan segala alasan permohonan dispensasi kawin tersebut dan juga sekaligus dampak-dampak yang mungkin terjadi jika dispensasi diberikan. Hakim harus menggali berbagai fakta hukum dan nilai-nilai sosial yang hidup di masyarakat dalam perkara yang sedang ditangani sehingga memberikan rasa keadilan bagi masyarakat sebagaimana yang dinyatakan dalam UU No. 4 Tahun 2004 tentang Kekuasaan Kehakiman Pasal 28 ayat (1) yang berbunyi bahwa Hakim wajib menggali, mengikuti, dan memahami nilai-nilai hukum dan rasa keadilan yang hidup dalam masyarakat.

Pertimbangan hakim dalam mengabulkan maupun menolak permohonan dispensasi kawin ini akan menimbulkan implikasi hukum atau akibat hukum. Akibat hukum merupakan akibat yang ditimbulkan oleh peristiwa hukum. ${ }^{7}$ Sedangkan peristiwa hukum diartikan sebagai peristiwa kemasyarakatan yang membawa akibat yang diatur oleh hukum. ${ }^{8}$

Di satu sisi apabila permohonan dikabulkan, maka secara legal akan menimbulkan semakin maraknya perkawinan di bawah umur. Masyarakat akan memandang bahwa pengadilan turut memberikan peluang besar bagi perkawinan di bawah umur, sehingga melanggar hak anak seperti halnya hak atas pendidikan, hak atas kesehatan, serta hak untuk tumbuh dan berkembang. Dengan demikian, peran hakim sangat penting dalam melindungi hak anak dalam pemeriksaan perkara Dispensasi Kawin agar pemberian izin dispensasi tersebut memang demi kepentingan terbaik bagi anak.

Namun, dengan mengabulkan permohonan Dispensasi Kawin tersebut, bukan berarti hakim tidak turut mencegah perkawinan di bawah umur, bahkan justru lebih memberikan kepastian, kemanfaatan dan keadilan bagi anak. Jika tidak dikabulkan justru akan mendatangkan madharat/bahaya yang lebih besar. Sehingga, dalam mengadili permohonan dispensasi kawin ini, Hakim benar-benar

${ }^{6}$ Data diperoleh dari materi presentasi oleh Dr. H. Purwosusilo, S.H., M.H. (Hakim Agung MA RI) dengan judul "Peran Hakim Melindungi Anak dalam Perkara Dispensasi Kawin" pada tanggal 16 Oktober 2020. hlm. 104

${ }^{7}$ J.B. Daliyo, Pengantar Ilmu Hukum, (Jakarta: PT. Gramedia P ustaka Utama, 1992),

${ }^{8}$ Ibid., hlm. 101. 


\section{Zurnal Negara dan $\mathcal{X}$ eadilan \\ p-ISSN 2302-7010 e-ISSN 2721-9801}

harus menggali, mengikuti, dan memahami nilai-nilai hukum dan rasa keadilan yang hidup dalam masyarakat dengan mempertimbangkan dari berbagai aspek sebagaimana telah diatur dalam ketentuan UU Perkawinan dan Perma Nomor 5 Tahun 2019, sehingga "alasan sangat mendesak" untuk melakukan perkawinan di bawah umur terpenuhi.

Memang tidak ada penjelasan secara rinci tentang alasan yang termasuk "alasan sangat mendesak" sebagaimana ketentuan Pasal 7 ayat (2) UU Nomor 16 Tahun 2019. Dalam penjelasan pasal tersebut menerangkan bahwa alasan mendesak tersebut harus disertai bukti-bukti pendukung yang cukup, yaitu surat keterangan yang membuktikan bahwa usia mempelai masih di bawah ketentuan undang-undang dan surat keterangan dari tenaga kesehatan yang mendukung pernyataan orang tua bahwa perkawinan tersebut sangat mendesak untuk dilaksanakan. ${ }^{9}$ Dapat diartikan bahwa yang dimaksud surat keterangan yang membuktikan bahwa usia mempelai masih di bawah ketentuan undang-undang adalah akta kelahiran anak yang menunjukan usia masih di bawah 19 tahun, sedangkan surat keterangan dari tenaga kesehatan yang mendukung pernyataan orang tua bahwa perkawinan tersebut sangat mendesak untuk dilaksanakan dapat diartikan sebagai surat keterangan dari tenaga kesehatan yang menyatakan bahwa anak sudah hamil sehingga menjadi alasan sangat mendesak untuk dilaksanakan perkawinan. Berdasarkan penafsiran tersebut, "alasan sangat mendesak" tersebut hanya mencakup anak yang sudah hamil yang menjadi alasan tidak ada pilihan lain dan sangat terpaksa harus dilangsungkan perkawinan. Alasan hamil di luar nikah menjadi alasan sangat mendesak karena memiliki akibat hukum paling besar baik bagi Pemohon dan juga anak yang dimohonkan dispensasi dan status hukum anak yang dilahirkannya nanti. Hamil di luar nikah akan menimbulkan aib dan rasa malu baik keluarga maupun anak karena hamil tanpa suami dan status hukum anak yang akan dilahirkan nanti juga akan tidak jelas, sehingga pernikahanlah yang menjadi solusi terakhir untuk mengurangi akibat hukum tersebut.

Jika dilihat dari penafsiran tersebut, memang hanya karena alasan hamil di luar nikah lah yang masuk kategori alasan sangat mendesak. Namun, tidak menutup kemungkinan alasan sangat mendesak tersebut atas dasar alasan selain hamil di luar nikah. Karena memang dalam UU Nomor 16 Tahun 2019 dapat dimaknai secara luas dengan mempertimbangkan aspek moral, agama, adat dan budaya, aspek psikologis, aspek kesehatan, dan dampak yang ditimbulkan. Hal tersebut sebagaimana penjelasan Pasal 7 ayat (3) UU Nomor 16 Tahun 2019 bahwa pemberian dispensasi oleh Pengadilan Agama bagi mereka yang beragama Islam dan Pengadilan Negeri bagi yang beragama lainnya berdasarkan pada semangat pencegahan perkawinan anak, pertimbangan moral, agama, adat dan budaya, aspek psikologis, aspek kesehatan, dan dampak yang ditimbulkan. Hakim harus menggali dari berbagai aspek tersebut dan nilai-nilai yang ada di masyarakat sehingga dapat memberikan keadilan dan memberi perlindungan hukum bagi anak yang dimohonkan dispensasi. Oleh sebab itu, tidak menutup kemungkinan alasan mendesak selain hamil di luar nikah akan dikabulkan oleh hakim setelah hakim mempertimbangkan permohonan dispensasi kawin dari berbagai aspek tersebut.

${ }^{9}$ Penjelasan Pasal 7 ayat (2) UU Nomor 16 Tahun 2019 


\section{$\mathcal{H}$ urnal Negara dan Keadilan \\ p-ISSN 2302-7010 e-ISSN 2721-9801}

Di sisi lain, apabila permohonan dispensasi kawin ditolak juga akan menimbulkan akibat hukum lainnya. Ditolaknya permohonan tersebut karena selama pemeriksaan ditemukan fakta persidangan bahwa tidak ada alasan yang sangat mendesak untuk dilangsungkan perkawinan bagi anak. Meskipun ditolaknya permohonan Dispensasi Kawin tersebut turut andil dapat mencegah perkawinan di bawah umur, sehingga turut melindungi hak anak seperti hak atas pendidikan, hak atas kesehatan, serta hak untuk tumbuh dan berkembang, namun hal tersebut juga akan menimbulkan akibat hukum lainnya antara lain seperti banyaknya nikah siri di bawah umur, itsbat nikah atas nikah siri di bawah umur, dan hamil di luar nikah.

\section{PENUTUP}

Perlindungan hak-hak anak dalam pemeriksaan perkara permohonan Dispensasi Kawin dilakukan atas dasar kepentingan terbaik bagi anak. Proses pemeriksaan perkara permohonan Dispensasi Kawin mengacu pada Perma Nomor 1 Tahun 2019 tentang Pedoman Mengadili Permohonan Dispensasi Kawin di Pengadilan. Adapun bentuk perlindungan hak-hak anak dalam pemeriksaan perkara permohonan Dispensasi Kawin meliputi: 1) Diperiksa oleh Hakim Tunggal yang kompeten, 2) Memberikan rasa nyaman di persidangan, 3) Menghadirkan anak dalam proses pemeriksaan, 4) Hakim menghadirkan dan memberi nasihat kepada Orang Tua, Anak, Calon Suami/Isteri dan Orang Tua/Wali Calon Suami/Isteri, 5) Mengutamakan kepentingan terbaik untuk anak, dan 6) Pertimbangan hukum oleh hakim yang mewujudkan kepastian, kemanfaatan dan keadilan bagi anak.

Dispensasi kawin dalam rangka perlindungan hak anak akan menimbulkan implikasi hukum baik permohonan tersebut dikabulkan ataupun ditolak. Apabila dikabulkan oleh Hakim akan memperbanyak tingkat perkawinan di bawah umur secara legal, apabila ditolak akan menimbulkan akibat hukum lainnya seperti banyaknya nikah siri di bawah umur, itsbat nikah atas nikah siri di bawah umur, dan hamil di luar nikah. Meskipun demikian, dalam hal mengabulkan permohonan dispensasi kawin, Hakim harus menggali nilai-nilai yang ada di masyarakat, sehingga terpenuhi alasan sangat mendesak yang menjadi syarat permohonan dispensasi kawin di pengadilan.

\section{DAFTAR PUSTAKA}

Undang-Undang Dasar Negara Republik Indonesia Tahun 1945

Undang-Undang Nomor 1 Tahun 1974 tentang Perkawinan

Undang-Undang Nomor 23 Tahun 2002 tentang Perlindungan Anak

Undang-Undang Nomor 35 Tahun 2014 tentang Perubahan atas Undang-Undang Nomor 23 Tahun 2002 tentang Perlindungan Anak

Undang-Undang Nomor 16 Tahun 2019 tentang Perubahan Atas Undang-Undang Nomor 1 Tahun 1974 tentang Perkawinan

Peraturan Mahkamah Agung Republik Indonesia Nomor 5 Tahun 2019 tentang Pedoman Mengadili Permohonan Dispensasi Kawin

Daliyo, J.B. 1992. Pengantar Ilmu Hukum. Jakarta: PT. Gramedia Pustaka Utama. Kusumaatmadja, Mochtar. 2002. Konsep-konsep Hukum dalam Pembangunan. Bandung: Alumni. 


\section{Jurnal Negara dan $\mathcal{X}$ eadilan \\ p-ISSN 2302-7010 e-ISSN 2721-9801}

Permana, Sugiri dan Ahmad Zaenal Fanani, 2019. Dispensasi Kawin Dalam Hukum Keluarga di Indonesia, Kajian Atas Norma dan Praktek Hukum Acara Pasca Disahkannya UU No. 16 Tahun 2019 dan Perma Nomor 5 Tahun 2019.

Purwosusilo. 2020. Peran Hakim Melindungi Anak dalam Perkara Dispensasi Kawin. Jakarta: Mahkamah Agung 